Meningkatkan Keterampilan Siswa Menentukan Perbedaan.....

\title{
MENINGKATKAN KETERAMPILAN SISWA DALAM MENENTUKAN PERBEDAAN PERTUMBUHAN TANAMAN MELALUI CONTEXTUAL TEACHING AND LEARNING (CTL) PADA SISWA SD NEGERI TOMPOKERSAN 03 LUMAJANG
}

\author{
Oleh: \\ Nurilatih \\ nurliatih@gmail.com \\ Guru SDN Boreng 02 Kec. Lumajang Kab. Lumajang.
}

\begin{abstract}
The basic characteristics of a child are curious, positive dependence on friends, although sometimes they lack confidence in their own abilities. Learning is therefore interesting, if the learning experience is closely related to students' real life everyday. Therefore the solution to the learning strategy Contextual Teaching and Learning (CTL) is able to solve this learning problem. This study aims to describe the effectiveness of the Learning Strategy Contextual Teaching and Learning (CTL) in improving learning skills in determining differences in the size of living things in science subjects in class $2 \mathrm{~B}$ of Tompokersan Elementary School 03 Lumajang Regency. Research conducted with classroom action research models concluded thatlearning strategies for contextual teaching and learning effective(CTL) were able to improve students' skills in determining differences in the size of living things in grade 2 B students of SD Tompokersan 03 Lumajang.
\end{abstract}

Keywords: student skills, contextual teaching and learning

\begin{abstract}
ABSTRAK
Karakteristik mendasar dari seorang anak yaitu ingin tahu, ketergantungan positif pada teman, walaupun terkadang kurang percaya pada kemampuannya sendiri. Oleh karena itu pembelajaran menjadi menarik, jika pengalaman belajar erat terkait dengan kehidupan nyata siswa sehari-hari. Oleh karena itu solusi Strategi pembelajaran Contextual Teaching and Learning (CTL) mampu memecahkan problem pembelajaran ini. Penelitian ini bertujuan untuk mendeskripsikan efektifitas Strategi pembelajaran Contextual Teaching and Learning (CTL) dalam meningkatkan keterampilan belajar dalam menentukan perbedaan ukuran makhluk hidup pada mata pelajaran IPA di kelas 2B SDN Tompokersan 03 Kabupaten Lumajang. Penelitian yang dilakukan dengan model penelitian tindakan kelas menghasilkan kesimpulan bahwa Strategi pembelajaran Contextual Teaching and Learning (CTL) efektif mampu meningkatkan ketrampilan siswa menentukan perbedaan ukuran makhluk hidup pada siswa kelas 2 B SD Negeri Tompokersan 03 Lumajang.
\end{abstract}

Kata Kunci: keterampilan siswa, contextual teaching and learning

\section{A. Pendahuluan}

Proses belajar mengajar merupakan interaksi yang dilakukan antara guru dengan peserta didik dalam suatu situasi pembelajaran untuk mewujudkan tujuan pembelajaran yang sudah ditetapkan. Berbagai pendekatan dipergunakan oleh seorang guru yang sifatnya masih sentralisasi. Metode pembelajaran dengan pendekatan yang disentralkan pada guru adalah

Vol.DI. No.D2. April 2019

Jurnal Auladuna | 67 
metode ceramah. Aktivitas pembelajaran lebih didominasi seorang guru, baik kegiatan maupun pengambilan keputusan.

Karakteristik lain dari seorang anak, misalnya anak suka bicara, baik nyata maupun membual. Tidak terlepas dari karakteristik meniru, berbicara juga merupakan perbuatan meniru. Berbicara itu sendiri merupakan suatu aktivitas menyampaikan pendapat, gagasan, pemikiran dan perasaan kepada lawan bicara. Mengingat kemampuan bicara anak dipengaruhi oleh keterbatasan wawasan dan cara berpikirnya, maka gaya bahasa dan struktur bahasa mereka sederhana dan lugas. Oleh sebab itu, setiap pembicaraan mereka seringkali diikuti dengan gerakan tubuh. Anak menjadi banyak menunjukkan gerakan atau tingkah laku yang berlebihan sekedar sebagai ungkapan pemerjelas maksud dan tujuan.

Ada aspek mendasar dari pemahaman anak banyak bergerak. Gerakan badan atau yang dikenal dengan bahasa badan merupakan perwujudan dari pemikiran. Fenomena pemikiran bisa tumbuh dalam bentuk kreativitas kecerdasan. Selaras dengan pernyataan tersebut sebuah pendapat menyatakan, para pelajar kinestetik suka belajar melalui gerakan dan paling baik menghafal informasi dengan mengaso-siasikan gerakan dengan setiap fakta (Bobbi de Porter: 2005: 168). Guru tinggal menyampaikan caranya kepada siswa. Guru memberikan petunjuk dalam bentuk tugas-tugas yang diberikan sebelum pembelajaran dilaksanakan. Proses selanjutnya siswa akan menemukan sendiri melalui fakta di lapangan tentang aspek-aspek tertentu yang kadang tidak pernah diprediksikan oleh guru. Sedangkan untuk siswa yang tidak suka dengan bergerak, diprediksi akan termotivasi juga oleh pembelajaran CTL ini. Ketertarikan mereka dimungkinkan terjadi, karena adanya perubahan situasi pembelajaran dari situasi pembelajaran di dalam kelas menjadi pembelajaran di luar kelas. Disamping itu, karena adanya alam nyata yang lebih berkesan bagi siswa.

Penyampaian materi pertumbuhan makhluk hidup dalam penelitian ini menggunakan strategi pembelajaran Contextual Teaching and Learning (CTL). Metode Contextual Teaching and Learning merupakan suatu metode dengan kegiatan pembelajaran membawa anak didik ke dalam alam kenyataan. Dalam pembelajaran ini, kegiatan atau aktivitasnya perpusat pada anak. Anak diberi kesempatan untuk mengakses pengetahuan dan pengalaman melalui kenyataan selama pembelajaran di kelas tidak ditemui. Metode tersebut dipilih untuk mempermudah penanaman konsep tentang teknik mengamati perbedaan makhluk yang masih kecil atau baru lahir dibandingkan dengan makhluk hidup yang sudah dewasa. Berdasarkan latar belakang tersebut dilakukan penelitian dengan judul " Meningkatkan Keterampilan Siswa Menentukan Perbedaan Pertumbuhan Tanaman Melalui Contextual Teaching And Learning (CTL) Pada Siswa SD Negeri Tompokersan 03 Lumajang”

\section{B. Kajian Pustaka}

Materi pertumbuhan yang diberikan pada siswa kelas dua merupakan materi pembelajaran yang memperkenalkan bagaimana tanaman tumbuh dan berkembang yang ditunjukkan dalam bentuk perbedaan ukuran. Memperkenalkan materi pertumbuhan dengan hanya menerangkan perbedaan anak dan induk saja tidak cukup membekali pemahaman siswa tentang pertumbuhan tanaman. Untuk mendapatkan yang abstrak menjadi lebih jelas, mudah dipahami anak, dilakukan dengan memperkenalkan objek pembelajaran melalui kenyataan.

Untuk menghasilkan prestasi pembelajaran yang maksimal, yang menca-kup hasil evaluasi tiga aspek kompetensi siswa dan yang relevan dengan materi pertumbuhan tanaman, kepada siswa diajarkan mengkaitkan pengetahuan dengan kenyataan. Praktik pendidikan di sekolah pada hakikatnya diharapkan menjadikan siswa sebagai manusia yang memiliki kemampuan belajar untuk mengembangkan potensi dirinya, sehingga dengan mengamati dan

68 | Jurnal Auladuna

Vol.DI. No.DZ. April 2019 
mengalami sendiri diharapkan akan mampu menganalisa sesuai kemampuannya. Melalui paradigma baru terse-but diharapkan di kelas siswa aktif dalam belajar, aktif berdiskusi, berani menyampaikan gagasan dan menerima gagasan dari orang lain, dan memiliki kepercayaan diri yang tinggi (Zamroni, 2000).

Image tentang karakter anak sudah dikenal oleh para orang tua. Anak lebih identik dengan segala jenis kenakalan. Penilaian tentang kenakalan pada umumnya hanya dilihat dari satu sudut pandang saja. Anak yang banyak bicara, tidak patuh, suka mengganggu dikategorikan dalam kelompok kenakalan anak. Sedangkan anak adalah sebuah jiwa yang di dalamnya terdapat berbagai keunikan. Orang dewasa tertentu yang tidak pernah dan kurang jeli dalam mempelajari segi kejiwaan seorang anak hanya akan mengatakan bahwa tingkah laku yang berlebihan dari seorang anak adalah sebuah keterasingan dan kelainan, jika anak tidak dan atau sulit patuh terhadap aturan atau perintah yang diberikan oleh orang dewasa. Mereka mengistilahkan aktivitas semacam ini sebagai sebuah kenakalan.

Kehidupan dan pengetahuan serta perkembangan kepribadian anak dipengaruhi oleh lingkungan sekitarnya. Lingkungan yang dimaksud antara lain lingkungan keluarga, masyarakat dan sekolah. Relevansi ilmu pengetahuan alam dengan kehidupan sehari-hari di lingkungan anak perlu ditekankan. Dengan demikian pelajaran Sains yang didapatkan anak-anak akan lebih bermakna baginya dan dapat meninggalkan kesan atau sejarah tersendiri.

Wagner (2010:134) dan Change Leadership Group dari Universitas Harvard mengidentifikasi kompetensi dan keterampilan yang diperlukan oleh siswa dalam menghadapi kehidupan, dunia kerja, dan kewarganegaraan di abad ke-21 ditekankan pada tujuh (7) keterampilan berikut: (1) kemampuan berpikir kritis dan pemecahan masalah, (2) kolaborasi dan kepemimpinan, (3) ketangkasan dan kemampuan beradaptasi, (4) inisiatif dan berjiwa entrepeneur, (5) mampu berkomunikasi efektif baik secara oral maupun tertulis, (6) mampu mengakses dan menganalisis informasi, dan (7) memiliki rasa ingin tahu dan imajinasi.

Berdasarkan pandangan tersebut, guru melakukan upaya untuk meningkatkan hasil balajar siswa dengan pendekatan yang tepat. Salah satu pendekatan pembelajaran yang yang dapat meningkatkan kreativitas siswa adalah pendekatan kontektual. Dengan pendekatan kontekstual, siswa diarahkan untuk berpikir, menganalisa, mengaitkan antara materi yang diajarkan dengan situasi nyata siswa dan mendorong siswa membuat hubungan antara pengetahuan yang dimilikinya dengan kehidupan mereka sebagai anggota keluarga dan masyarakat

Proses belajar dalam pendekatan kontekstual berlangsung secara alamiah. Kegiatan siswa dalam bentuk bekerja dan mengalami sendiri, bukan mentransfer pengetahuan dari guru yang sifatnya mendengar dan mengetahui. Verbalisme tidak terjadi dalam pembelajaran kontekstual. Tugas guru dalam pendekatan ini adalah membantu siswa dalam mencapai tujuan pembelajaran. Guru berperan sebagai fasilitator, dinamisator, inspirator yang terangkum dalam strategi pembelajaran yang diterapkan kepada siswanya. Guru bukan pusat informasi. Siswa menemukan dan mendapatkan pengetahuan melalui pengalaman belajar dalam kenyataan.

Selaras dengan prinsip pengajaran Sains di sekolah dasar diantaranya, setiap langkah dalam pengajaran Sains hendaknya diusahakan melalui penyajian yang menarik untuk menghindarkan terjadinya tekanan. Guru diharapkan untuk melakukan perubahan kegiatan pembelajaran dan seluruh aspek pendukungnya misalnya dengan menyesuaikan media peraga pendidikan dengan materi dan tema pembelajaran, penentuan model penilaian yang mencakup aspek kognitif, afektif dan aspek psikomotor. Ketiga aspek penilaian ini saling berkaitan. Aspek psikomotor misalnya, tidak terlepas dari kognitif. Abdul Majid menyatakan Walaupun belajar ketrampilan psikomotorik mengutamakan gerakan-gerakan persendian dalam tubuh, namun

Vol.DI. No.D2. April 2019

Jurnal Auladuna | 69 
diperlukan pengamatan melalui alat indera dan secara kognitif yang melibatkan pengetahuan dan pengalaman (2006: 6). Melalui paradigma baru tersebut diharapkan di kelas siswa aktif dalam belajar, aktif berdiskusi, berani menyampaikan gagasan dan menerima gagasan dari orang lain, dan memiliki kepercayaan diri yang tinggi (Zamroni, 2000)

\section{METODE PENELITIAN}

Penelitian ini merupakan "Penelitian Tindakan Kelas" dengan dengan tiga siklus yang masing-masing siklus terdiri atas kegiatan: Planning, Implementing, Observing, dan Reflecting seperti tertera pada Gambar 3.1 Tahap-tahap penelitian Tindakan Kelas

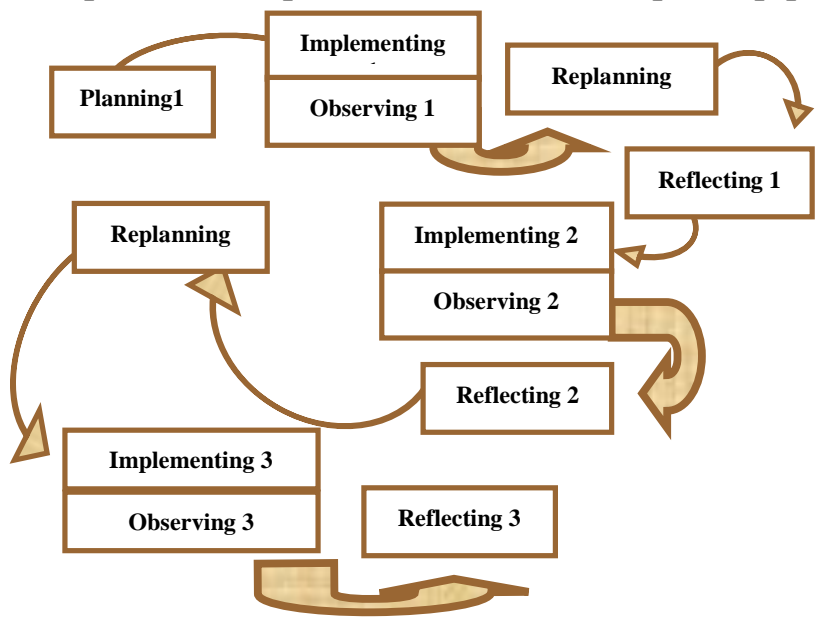

Gambar 3.1 Tahap-tahap Penelitian Tindakan Kelas

Subjek penelitian ini terdiri dari seluruh siswa-siswi kelas 2 B Sekolah Dasar Negeri Tompokersan 03 Kecamatan Lumajang, Kabupaten Lumajang dengan rincian: jumlah siswa laki-laki 15 anak dan siswa perempuan 17 anak, jadi jumlah siswa semua 32 anak.

Penelitian dilaksanakan sejak tanggal 26 Pebruari 2007 sampai tanggal 26 Maret 2007 dengan persiapan perencanaan pembelajaran dimulai pada tanggal 12 dan 13 Maret 2007, baik persiapan dari pihak guru maupun penyampaian informasi kepada siswa. Implementasinya dilaksanakan pada saat pembelajaran berlangsung yaitu tanggal 20 dan 23 Maret 2007.

Sedangkan Reflecting dilaksanakan pada akhir pembelajaran, yaitu pada 10 menit pada kegiatan akhir pembelajaran dengan jadwal pelaksanaan seperti tertera pada Tabel 3. 1 Jenis dan Jadwal Penelitian.

Tabel 3.1 Jenis dan Jadwal Kegiatan Penelitian

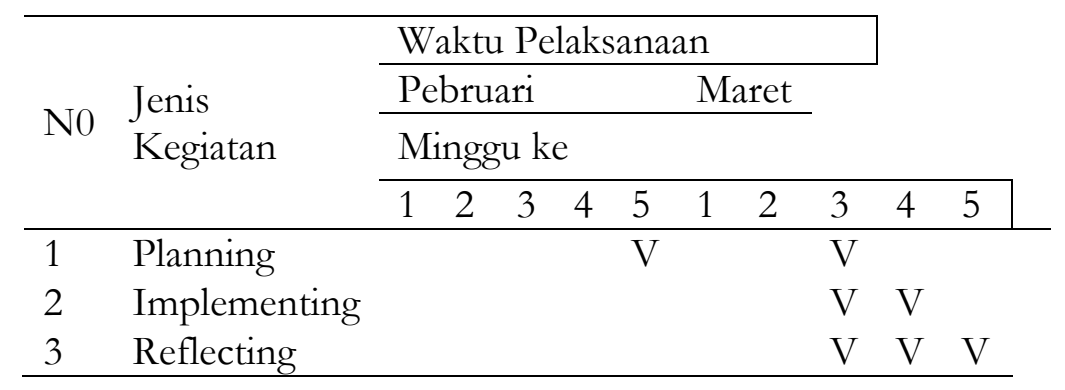

Berdasarkan variabel yang tercantum pada Tabel 1.1 Ruang Lingkup Penelitian, maka instrumen penelitian ini menggunakan lembar Performance Assesment (PA) untuk mendapatkan 
hasil belajar berupa sikap afektif, porto folio, Pencil and Paper Test (PPT) untuk mendapatkan hasil belajar akhir dari satu pokok bahasan yaitu satu kompetensi dasar, dengan teknik pengumpulan data untuk performance assesment menggunakan lembar observasi dan sumber datanya adalah dari siswa. Sedangkan porto folio digunakan untuk mendapatkan laporan kegiatan CTL dengan cara mencatat setiap kegiatan yang dilakukan oleh siswa yaitu mencatat hasil pengamatan tentang tinggi induk hewan dan anaknya, tinggi tumbuhan dan anaknya. Ciri-ciri hewan yang masih kecil dan yang sudah dewasa. Ciri-ciri tumbuhan yang masih kecil dan setelah besar.

Siklus I, Planning Strategi pembelajaran dipersiapkan dengan langkah-langkah pelaksa-naan seperti yang dijabarkan dalam Rencana Pelaksanaan (RPP) pada Lampiran 1 a. RPP 1. Instrumen: Performance and Assesment (PA), dan Pencil and Paper Test (PPT), Media pembelajaran antara lain: penggaris, pensil, penghapus, notes sebagai catatan hasil pengamatan, dan tanaman di sekitar kelas. Guru dan siswa menyiapkan alat-alat yang akan digunakan untuk pengamatan dan demontrasi yaitu alat ukur: mistar dan penggaris, Sumber Belajar: Hariyanto. SAINS untuk kelas 2. Erlangga 2004. LKS. Cara Belajar Praktis. Penerbit Karya Bakti., Lumajang. 2008. Implementing Pelaksanaan pembelajaran tidak sesuai dengan perencanaan yang tercan-tum dalam Rencana Pelaksanaan Pembelajaran (RPP). Ketika pembelajaran berlangsung, siswa pasif terhadap kegiatan pembelajaran, siswa tidak bermi-nat terhadap keterangan guru, dan ketika anjuran untuk konsentrasi terhadap pembelajaran disampaikan oleh guru kepada siswa, situasi kelas menjadi tertib. Situasi yang tampak tertib tersebut ternyata bukan fokus terhadap pembelajaran. Mereka tertib karena takut mendapat peringatan guru. Ada beberapa siswa yang menundukkan kepala. Setelah guru mendekati siswa, ditemukan siswa sedang bermain kartu di dalam laci mejanya. Observing Observing dilaksanakan pada saat Implementing. Proses evaluasi hanya sampai pada test kognitif. Sehingga hanya mendapatkan data nilai PPT dan porto folio. Tidak bisa mendapatkan nilai psikomotor dan afektif. Nilai portofolio didapatkan dari kliping siswa yaitu kumpulan gambar-gambar hewan dan tumbuhan yang menunjukkan perbedaan anak dan induk seperti tertera pada Lampiran 10. Reflecting Hasil Observing menunjukkan perlu adanya tindakan pembenahan perencanaan pembelajaran. Titik berat penekanan pembenahan difokuskan pada minat belajar siswa. Pembelajaran tidak akan bermakna dan mencapai prestasi maksimal bagi siswa, jika tidak ada motivasi terhadap pembelajaran. Di sisi lain, perlu adanya tindakan penanaman disiplin dalam pelaksanaan pembelajaran. Beberapa disiplin yang dimaksud antara lain: tertib (dalam arti situasi tidak gaduh oleh aktivitas bicara di luar topik pembelajaran), tidak ada siswa yang bertengkar atau berkelahi. Hasil pendapat siswa menunjukkan pemikiran yang tidak berhubungan dengan pembelajaran.

Tabel 3. 2 Pendapat Siswa Siklus I

\begin{tabular}{ll} 
Nama & Pendapat Siswa tentang Pembelajaran \\
Siswa & Pertumbuhan \\
\hline Afrah & : Saya suka bercerita \\
Bella & : Saya senang belajar ke KWT. \\
& : Saya tidak suka ada teman \\
Ivon & bertengkar \\
Intan & : Saya tidak tahu teman-teman ramai \\
\hline
\end{tabular}

Siklus II, Pllanning Berdasarkan Reflecting pada Siklus I dilakukan perbaikan isi RPP 2 seperti tertera pada Lampiran 1b dengan membuat perubahan program kegiatan pembelajaran. Pada RPP 1 pembelajaran dilaksanakan di dalam kelas, sedangkan pada RPP 2 dilaksanakan di

Vol.DI. No.D2. April 2019

Jurnal Auladuna | 71 
luar kelas. Siswa langsung mengamati perbedaan tumbuhan sebagai anak dan sebagai induk langsung pada tumbuhannya. Implementing Kegiatan pembelajaran pada siklus ke 2 telah cukup sesuai dengan RPP 2. Kedisiplinan meningkat, terutama kedisiplinan pada saat siswa mengamati perbedaan tinggi antara tumbuhan yang masih kecil dan sudah besar dan ketika kegiatan mengukur tinggi tumbuhan. Terjadi kebersamaan dalam bentuk kerjasama kelompok, meskipun ditemukan siswa yang masih tampak bertengkar. Mereka saling adu pendapat masing-masing tentang menentukan ukuran panjang dengan menggunakan penggaris ataukah mistar kain. Mistar kain untuk mengukur lingkaran tubuh tumbuhan. Penggaris digunakan untuk mengukur tinggi tumbuhan. Pada Siklus ke II ini, aspek afektif kerjasama bisa dievaluasi. Observing. Data hasil observing 2 menunjukkan bahwa aspek psikomotor masih belum membuktikan adanya semangat untuk berusaha mendapatkan data secara sungguh-sungguh. Ada beberapa siswa yang duduk melamun tidak ikut aktif dalam kegiatan pembelajaran. Ada juga seorang siswa yang seperti terlibat dalam aktivitas pengamatan. Ternyata siswa tersebut tidak benar-benar aktif. Siswa tersebut hanya berpura-pura aktif, karena adanya ancaman mendapatkan nilai jelek jika tidak aktif dalam pembelajaran. Ada siswa yang memanfaatkan kegiatan di luar kelas ini untuk bebas bergurau. Hal semacam ini ditanggulangi dengan penanaman disiplin. Perkembangan yang bagus adalah guru bisa mengevaluasi aspek afektif kerjasama. Reflecting. Berdasarkan hasil observing 2, dilakukan reflecting, baik dari segi nilai PPT, PA maupun pendapat siswa seperti tertera pada Tabel 3.3 Pendapat Siswa Siklus II.

Siklus III. Planning RPP 3 diperbaiki dengan cara melakukan tindakan perbaikan pada bagian program mengarahkan ketertiban kepada siswa. Penekanan disiplin dilakukan untuk menanggulangi beberapa tindakan siswa yang melanggar peraturan. Peraturan ini dikemukakan sebelumnya antara guru dan siswa. Ditanamkan kesadaran kepada siswa, bahwa kegiatan ini adalah kegiatan pembelajaran. Siswa yang aktif akan mendapatkan nilai yang baik dan yang tidak aktif mendapatkan nilai jelek. Sekaligus menambah satu tenaga guru untuk mengawasi dan mengarahkan proses pembelajaran yaitu seperti tertera pada Lampiran 1c RPP 3. Hal ini dimaksudkan untuk menguji secara nyata kom-petensi siswa dinilai dari berbagai aspek dalam strategi pembelajaran CTL. Implementing Berdasarkan observasi berupa data Performance Assesment seperti tertera pada Lampiran 4 dan pendapat siswa Siklus II pada Lampiran 6, serta hasil PPT Siklus II Tabel 4.2 pada Lampiran $3 \mathrm{~g}$ dilakukan implmenting 3. Pembelajaran pada implementing 3 lebih sempurna dan mantap. Pada siklus ke 3 ini siswa lebih aktif, sungguhsungguh dalam setiap aktivitas dan tindakan. Teman kelompok menuntut setiap anggotanya untuk bekerjasama. Observing Hasil Observing 3 menunjukkan, bahwa aspek kognitif, afektif dan motorik sudah sempurna. Kebersamaan dan kemandirian siswa menunjukkan kepercayaan diri, tertib, trampil dalam menentukan pengukuran tinggi tumbuhan dan mencari ciri-ciri yang membedakan tumbuhan sebagai anak dan induk. Setiap siswa mempunyai tanggung jawab, sebab guru menugasi setiap siswa mencatat setiap tahap kegiatan. Di samping itu, diadakan diskusi kelompok sebelum mempresentasikan hasil diskusinya. Reflecting. Berdasarkan penilaian dalam Observing menghasilkan data $P A$ dan PPT. Kemudian dilakukan tindakan terakhir yaitu pendataan tentang pendapat siswa seperti tertera dalam Tabel 3.4 Pendapat Siswa Siklus III pada Lampiran 6 c yang sebagian dapat dilaporkan sebagai berikut.

Tabel 3. 4 Pendapat Siswa Siklus III

\begin{tabular}{lll}
\hline No & Nama & \\
\hline 1 & Yudha & Pendapat Siswa \\
& & $\begin{array}{l}\text { : Saya lebih suka bercerita } \\
\text { Sang buka bertengkar }\end{array}$
\end{tabular}

72 | Jurnal Auladuna

Vol.DI. No.T2. April 2019 
3 Devi. W. : Saya tidak suka ada teman yang bermain kartu. Saya tidak bisa belajar

4 Kemal : Sangat senang : Senang karena bisa

5 Intan mengukur

\section{Hasil dan pembahasan}

Standard Kriteria Ketuntasan Minimal (KKM) mata pelajaran Sains adalah 75. Pembelajaran Sains dikatakan berhasil jika $85 \%$ nilai siswa telah melampaui standard KKM. Hasil penelitian mengenai prestasi siswa dalam ketrampilan membedakan makhluk hidup yang dipandang dati sudut ukurannya, baik kognitif, afektif maupun psikomotor dapat dilaporkan sebagai berikut.

\section{Data Nilai Aspek Kognitif}

a). Pada Siklus I Nilai aspek kognitif siswa didapatkan melalui data dari instrumen penilaian setiap individu PPT seperti tertera pada Gambar 4.1 PPT Komulatif Siswa Siklus I. Nilai A 3,1 \%, B 31,3\%, C 56,3\%, D 9,8\%, dan E $0 \%$ diperjelas oleh Gambar 4.1 PPT Siklus I

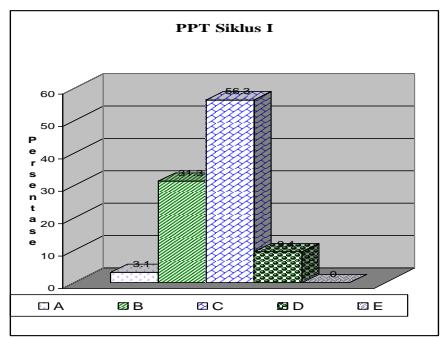

Gambar 4.1 PPT Komulatif Siswa Siklus I

b). Pada Siklus II, Data nilai aspek kognitif siswa individu seperti tertera pada Gambar 4.2 PPT Komulatif Siklus II seperti berikut. dengan nilai A 21,9\%, B 59,4 \%, C 18,8 \%, D 0 $\%$, dan E $0 \%$

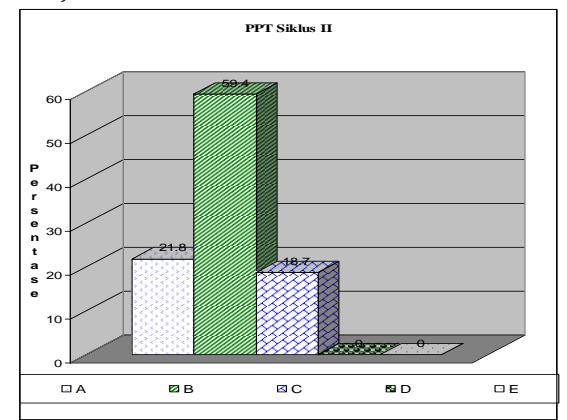

Gambar 4.2 PPT Komulatif Siswa Siklus II

c). Pada Siklus II Data nilai aspek kognitif siswa individu seperti tertera pada Gambar 4.3 PPT Komulatif Siklus II dengan nilai A 71,9\%, B 21,9\%, C 6,3 \%, D 0 \%, dan E 0 \%. 


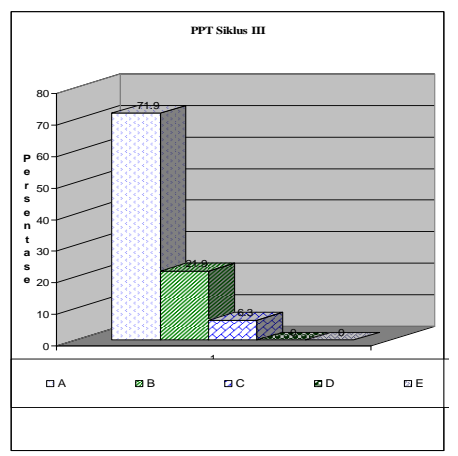

Gambar 4.3 PPT Komulatif Siswa Siklus III

\section{Data Nilai Aspek Afektif}

a. Pada Siklus I, Afektif didapatkan dengan menggunakan instrumen penilaian PA yaitu Kemandirian dan kerjasama. Sedangkan PA negatif yaitu kurang disiplin dan Spoiled (nakal, banyak tingkah dan sulit patuh).

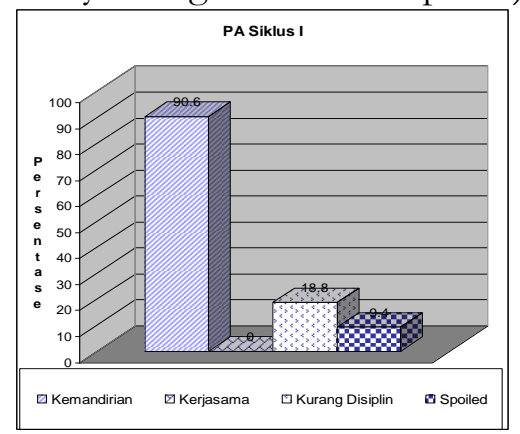

Gambar 4.4 PA Siklus I

b. Siklus II

Tabel 4.5.1 PA Individu Siklus II pada Lampiran 4 d, merupakan pero-lehan data mentah tiap individu. Secara keseluruhan data komulatif PA siswa seperti tertera pada Tabel 4.5 Tabel PA Komulatif Siswa Siklus II berikut. Diperjelas dibaca oleh Gambar 4.5 PA Komulatif Siswa Siklus II berikut.

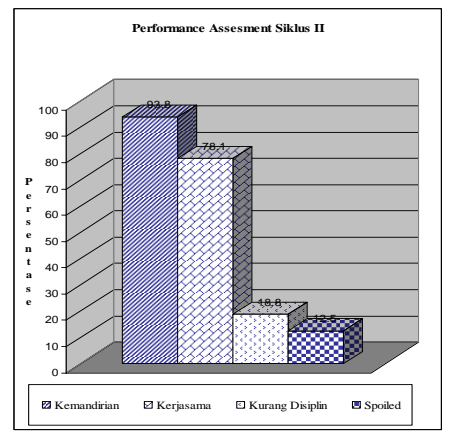

Gambar 4.5 PA Komulatif Siswa Siklus II

Pada Siklus III, Tabel 4.6.1 PA Individu Siklus III pada Gambar 4.6 PA Komulatif Siswa Siklus III 


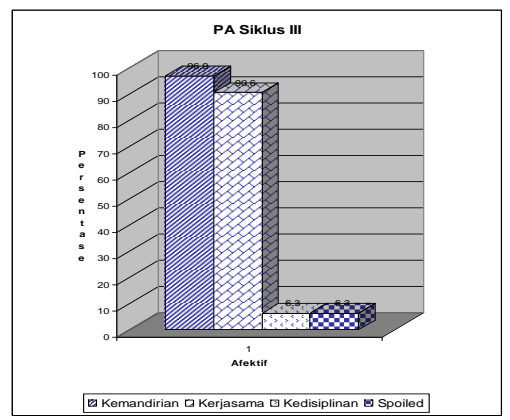

Gambar 4.6 PA Kumulatif Siswa Siklus III

\section{E. Pembahasan Hasil Penelitian}

Kriteria Ketuntasan Minimal (KKM) nilai Sains kelas 2 B adalah 70. Hal ini berarti nilai terendah ádalah 70. Ditargetkan di kelas $2 \mathrm{~B}$, nilai diatas 70 mencapai $85 \%$ dari jumlah siswa. Hal ini berarti, presentase keseluruhan KKM Sains kelas $2 \mathrm{~A}$ adalah 85\%.

1. Siklus I.

Berdasarkan data PPT pada Tabel 4.1 Nilai A 3.1\%, B 31,3\%, C 56,3\%, C 9,4\%, dan D $0 \%$. Menunjukkan, bahwa pada Siklus I pencapaian nilai di atas 70 adalah $34,4 \%$. Persentase tersebut belum memenuhi standard KKM. Maka perlu dilakukan tindakan perbaikan strategi pembelajaran.

Sedangkan data lain didapatkan dari data PA pada Tabel 4.4 P A Komulatif Siswa Siklus I menunjukkan bahwa siswa telah $90.6 \%$ kemandirian, 0.\% kerjasama, $18.8 \%$ kurang disiplin, dan $9.4 \%$ siswa tergolong Spoiled. Aspek afektif kerjasama tidak bisa dimunculkan dalam proses pembelajaran ini, karena siswa hanya mendengarkan ceramah guru.

Ketika diutarakan Reflecting tentang pendapat siswa yang berbunyi "Apa pendapatmu tentang pelaksanaan pembelajaran Sains hari ini?" Hasil pendapat siswa menunjukkan pemikiran yang tidak berhubungan dengan pembelajaran. Pada Reflecting I peneliti bertanya-tanya sendiri tentang pendapat siswa yang jauh menyimpang dari pertanyaan guru tersebut. Pendapat siswa seperti tertera pada Tabel 3.2 Pendapat Siswa Siklus I. Dugaan sementara peneliti pada saat itu yakni

a. Pernyataan siswa sulit dipahami, karena pengetahuan bahasa yang kurang.

b. Pemikiran yang masih sederhana.

c. Dari poin 1 dan ke 2, perkiraan peneliti tentang pengertian pendapat siswa adalah siswa tidak suka dengan pembelajaran Sains hari itu. Pernyataan yang menunjukkan tentang ketidak-sukaan terhadap pembelajaran memang tidak secara tersurat tetapi tersirat atau secara implisit. Meskipun peneliti membuat dugaan perkiraan, tindakan bukan tidak beralasan. Peneliti mencoba melakukan strategi baru agar dugaan tersebut bisa terjawab.

Reflecting 1 sudah dilakukan. Berdasarkan hasil data siswa pada seluruh aspek kemampuan menunjukkan prestasi tergolong cukup. Sedangkan dari pendapat siswa menunjukkan adanya motivasi yang kurang, dalam arti siswa bingung harus berpendapat tentang pelaksanaan pembelajaran.

Tindakan yang dilakukan pada permasalahan tersebut adalah mengubah strategi pembelajaran dengan melakukan pendekatan baru. Pendekatan baru tersebut adalah pendekatan kontektual.

2. Siklus II.

Vol.DI. No.D2. April 2019

Jurnal Auladuna | 75 
Pendekatan ini telah membuat perubahan prestasi yang berarti. Data prestasi kognitif siswa Siklus II secara komulatif dapat dilaporkan seperti tertera pada Tabel 4.2 PPT Komulatif Siswa Siklus II. Dari data tersebut menunjukkan peningkatan yang berarti yaitu Kategori nilai A pada Siklus I 3,1 \% menjadi 21,9\% pada Siklus II, B 31,3\% menjadi $59,4 \%$, C 56,3 \% menjadi 18,8 \% karena nilai mereka termasuk dalam kategori B dan D 9,8 $\%$ menjadi $0 \%$. Data tersebut memberikan bukti yang akurat tentang penanaman konsep dengan menggunakan pendekatan kontekstual lebih mengena dan mudah. Guru bisa memberikan gambaran lebih jelas.

Kemampuan Afektif Siswa secara komulatif seperti tertera pada Tabel 4.4 Kategori sikap $90.6 \%$ kemandirian menjadi 96,3 \%. Perubahan mendasar tampak pada aspek kategori sikap kerjasama dari $0 \%$ menjadi 78,1 \%, karena pada Siklus I pembelajaran bersifat pasif pada sisi siswa atau satu arah saja. Guru hanya menggunakan dua metode yaitu ceramah dan tanya jawab. Pada metode tersebut tidak bisa didapatkan hasil penilaian aspek kerjasama. Siswa yang tergolong kurang disiplin tidak mengalami perubahan. Sedangkan siswa yang termasuk kategori Spoiled meningkat dari $9.4 \%$ menjadi $12,5 \%$. Hal ini terjadi karena adanya kesempatan besar untuk melakukan tindakan kebebasan. Ruang gerak yang luas, pengawasan guru kurang karena jarak yang jauh dari jangkauan guru. Setelah dilakukan Reflecting 2 dilampaui, didapatkan data pendapat siswa seperti Tabel 3.3 Lampiran $6 \mathrm{~b}$ menunjukkan antusias dan semangat yang tinggi terhadap pembelajaran dengan pendekatan Kontekstual.

Data aspek psikomotor dapat diketahui melalui portofolio hasil catatan siswa selama pembelajaran berlangsung seperti pada Lampiran 8 dalam portopolio tersebut dituliskan hasil catatan siswa tentang mengukur tinggi tumbuhan. Data tersebut ditulis oleh siswa yang telah ditunjuk oleh temannya sebagai notulis.

3. Siklus III

Prestasi kognitif dan Afektif siswa Siklus II, masih belum memenuhi $85 \%$ target yang dicanangkan guru di kelas $2 \mathrm{~B}$, sehingga dilakukan tindakan penelitian pada siklus ke III dengan melakukan pembenahan pada penanaman disiplin dan menambah satu guru pendamping untuk mengawasi dan mengarahkan jika terjadi penyimpangan pada proses pembelajaran. Di samping itu guru pendamping membantu siswa yang mengalami kesulitan dalam setiap tahap proses pembelajaran.

Data aspek kognitif siswa dapat dilaporkan seperti tertera pada Tabel 4.3 PPT Komulatif Siswa Siklus III. Dari data tersebut menunjukkan peningkatan yang berarti yaitu Kategori nilai A 21,9 \% menjadi 71,9\%, B 59,4 \% menjadi 21,9 \%, karena nilai mereka termasuk dalam kategori A, C 18,8 \% menjadi 6,3 \% dan D $0 \%$. Data tersebut memberikan bukti bahwa meskipun ruang gerak yang luas, suasana bebas bukan hal yang fatal nengga-galkan keberhasilan prestasi siswa. Kesuksesan tergantung bagaimana cara guru menyiasati setiap permasalahan yang terjadi. Dengan menambah satu tenaga guru, ternyata cukup membantu pendisiplinan proses pembelajaran.

Kemampuan Afektif Siswa secara komulatif seperti tertera pada Tabel 4.6 Kategori sikap Kemandirian 93,8 \% menjadi 96,9\%, Kerjasama $78.1 \%$, menjadi 90,6 \%, Kurang Disiplin $18.8 \%$ menjadi $6,3 \%$, Spoiled $12,5 \%$ menjadi $6,3 \%$, Suatu perubahan yang mendekati kesempurnaan. 6,3\% pelanggaran disiplin dilakukan siswa, karena siswa tersebut berasal dari latar belakang keluarga yang kurang perhatian dan kurang disiplin terhadap putranya.

\section{F. SIMPULAN}

76 | Jurnal Auladuna

Vol.DI. No.DZ. April 2019 
Strategi pembelajaran Contextual Teaching and Learning (CTL) mampu meningkatkan ketrampilan siswa menentukan perbedaan makhluk hidup berdasarkan ukuran pada siswa kelas 2 B SD Negeri Tompokersan 03 Lumajang,

Dibuktikan dengan hasil Performance Assessment unsur Kemandirian $90.6 \%$ kemandirian, 0.\% kerjasama, $18.8 \%$ kurang disiplin, dan $9.4 \%$ pada Siklus I menjadi $93.8 \%$ kemandirian, $78.1 \%$ kerjasama, $18.8 \%$ kurang disiplin, dan 12,5\% pada Siklus II menjadi $96.6 \%$ kemandirian, $90.6 \%$ kerjasama, $6.3 \%$ kurang disiplin, dan $6.3 \%$ pada Siklus III

Pencil and Paper Test nilai A 3,1 \%, B 31,3\%, C 56,3\%, D 9,8\%, dan E $0 \%$ pada Siklus I menjadi A 21,9 \%, B 59,4 \%, C 18,8 \%, D $0 \%$, dan E $0 \%$ pada Siklus II menjadi A 71,9 \%, B 21,9\%, C 6,3\%, D $0 \%$, dan E $0 \%$ pada Siklus III.

Keberhasilan strategi pembelajaran CTL tersebut dicapai dengan langkah-langkah, mengemukakan tujuan pembelajaran, demonstrasi penentuan perbedaan pengukuran tinggi tanaman, pelaksanaan CTL yang di dalamnya terjadi pelaksanaan evaluasi tiga aspek kompetensi yaitu kognitif, afektif dan psikomotor dengan menggunakan instrumen penilaian performance assesment, dan diakhiri pencil and paper test dan porto folio.

\section{DAFTAR RUJUKAN}

Departemen Pendidikan Nasional. 2004. Kurikulum 2004. Standar Kompetansi Mata Pelajaran Kelas II Sekolah Dasar dan Madrasah Ibtidaiyah. Jakarta: Depdiknas.

DePoter, B. dkk. 2000. Quantum Learning Mempraktikkan Quantum Learning di Ruang- Ruang Kelas, Kaifa, Bandung.

Fajri. 2002. Kamus Bahasa Indonesia. Jakarta: PT Gramedia.

Hernowo. 2007. Menjadi Guru yang Mau dan Mampu Mengajar secara Menyenangka. Bandung: Mizan Learning Center.

Majid, A. 2006. Perencanaan Pembelajaran Mengembangkan Standar Kompetensi Guru. Bandung: PT

Remaja Rosdakarya.

Suparno, P. (1997). Filsafat konstruktivisme dalam pendidikan. Yogyakarta: Kanisius.

Wagner, T. 2010. Overcoming The Global Achievement Gap (online). Cambridge, Mass., Harvard University.

Zamroni. (2000). Paradigma Pendidikan Masa Depan. Yogyakarta: Bigraf Publishing.

Vol.DI. No.D2. April 2019 